\title{
EXPERIMENTAL STUDY ON THE EFFECTS OF BASKETBALL ON PLANTAR PRESSURE DISTRIBUTION OF JUVENILES
}

\author{
Lei HU*
}

Chongqing Technology and Business University, Institute of Physical Education, Chongqing 400067, China

Received: 05.08.2017

Accepted: 16.02 .2018

https://doi.org/10.24264/Ifj.18.1.1

\section{EXPERIMENTAL STUDY ON THE EFFECTS OF BASKETBALL ON PLANTAR PRESSURE DISTRIBUTION OF JUVENILES}

ABSTRACT. With professional basketball games sweeping around the world, basketball is becoming more and more popular among juveniles. Therefore, it is of great significance to study the biomechanical effects of basketball on foot pressure and evaluate the impacts of basketball on the foot health development of juveniles in a scientific and objective manner. In this paper, by setting up an experimental group and a control group and using the RS-footscan force-measuring system, we attempt to test and analyze the planta support period, peak plantar pressure intensity, plantar impulse and foot axis angle of juveniles. The experimental results show that long-term basketball sports has a positive effect on the foot health development of juveniles. This study is very helpful to promoting basketball sports and preventing basketball injuries. KEY WORDS: basketball, experimental verification, experimental group, control group, plantar pressure.

STUDIU EXPERIMENTAL PRIVIND INFLUENTA PRACTICĂRII BASCHETULUI ASUPRA DISTRIBUTIEI PRESIUNII PLANTARE LA TINERI REZUMAT. Având în vedere amploarea jocurilor profesioniste de baschet la nivel mondial, baschetul devine din ce în ce mai popular printre tineri. Prin urmare, este foarte important să se studieze efectele biomecanice ale practicării baschetului asupra presiunii piciorului şi să se evalueze impactul acestuia asupra dezvoltării sănătăţii piciorului la tineri într-o manieră ştiinţifică şi obiectivă. În această lucrare, prin înfiinţarea unui grup experimental şi a unui grup martor şi prin utilizarea sistemului de măsurare a forţei RS-footscan, sunt testate şi analizate perioada de susţinere a boltei plantare, intensitatea presiunii plantare maxime, impulsul plantar şi unghiul axei piciorului la tineri. Rezultatele experimentale arată că practicarea baschetului pe termen lung are un efect pozitiv asupra dezvoltării sănătăţii piciorului la tineri. Acest studiu este foarte util pentru promovarea baschetului şi prevenirea rănilor apărute în timpul practicării acestui sport. CUVINTE CHEIE: baschet, verificare experimentală, grup experimental, grup martor, presiune plantară.

ETUDE EXPÉRIMENTALE SUR LES EFFETS DU BASKET-BALL SUR LA DISTRIBUTION DE LA PRESSION PLANTAIRE CHEZ LES JEUNES

RÉSUMÉ. Compte tenu de l'importance des jeux de basket-ball professionnels dans le monde, le basket-ball est de plus en plus populaire auprès des jeunes. Il est donc très important d'étudier les effets biomécaniques du basket-ball sur la pression du pied et d'évaluer son impact sur le développement de la santé des pieds chez les jeunes d'une manière scientifique et objective. Dans cet article, par la création d'un groupe expérimental et d'un groupe de contrôle et à l'aide du système de mesure de la force RS-footscan, la période d'entretien de l'installation, l'intensité du maximum de pression plantaire, l'impulsion plantaire et l'angle de l'axe du pied sont testés et analysés chez les jeunes. Les résultats expérimentaux montrent que la pratique du basket-ball à long terme a un effet positif sur le développement de la santé des pieds chez les jeunes. Cette étude est très utile pour promouvoir le basketball et prévenir les blessures survenant lors de la pratique de ce sport.

MOTS CLÉS: basketball, vérification expérimentale, groupe expérimental, groupe de contrôle, pression plantaire.

* Correspondence to: Lei HU, Chongqing Technology and Business University, Institute of Physical Education, Chongqing 400067, China, email: 289592324@qq.com 


\section{INTRODUCTION}

Plantar pressure refers to the interaction force between the planta and the support surface. Plantar pressure distribution has something to do with contact area, moving posture, weight and other factors. In recent years, studies have been more intensive on foot pressure because it not only reflects foot functions, but also shows how body postures are controlled during different sports [1]. Currently, plantar pressure research has gone further into the footwear industry, medical orthotics, medical rehabilitation, sports biomechanics and other fields. Analyzing competitive sports based on plantar pressure is also a hot subject at present.

As an increasingly popular sport among juveniles, basketball has a lot of requirements for the human foot. Many basketball movements rely on feet, such as sudden stop, turn, side sliding and jump shot. Foot movements are the basis for completing a series of basketball movements [2]. Studying the dynamic features of foot movements in basketball games and understanding features like plantar impulse and plantar pressure can, on one hand, help protect feet and prolong their sport life span, and on the other hand, effectively verify the positive role that basketball is playing in promoting the foot health development of juveniles [3].

In this paper, through experimental study, we test the plantar pressure distribution of basketball players and ordinary juveniles using the RS-footscan force-measuring system. By setting up an experimental group and a control group, we measure, compare and analyze the planta support period, peak plantar pressure intensity, plantar impulse and foot axis angle. The experimental results indicate that playing basketball on a long-term basis can help juveniles build up physical endurance of their feet and improve their forefoot strength and foot stability.

\section{METHODS}

\section{Physiological Mechanical Analysis of Foot}

The foot is a complex structure of 26 bones, 33 joints, 126 ligaments, muscles and nerves arranged in a network-like form [4]. Its basic functions are to support the weight of the human body, act as a buffer to absorb impacts, propel the leg forward and help maintain balance. In addition to absorbing the ground reaction forces and supporting the body weight, as an "all-round" bone union, another important function of foot is to transform the force of the muscular tissues from the thigh to the shank to effective displacement to complete a variety of movements [5].

Basketball can be classified into ballholding and non-ball-holding sports. In basketball games, the foot acts as a buffer to adjust the impacts of gravity center shifts on the body and provides power and buffer forces when a player makes a turn, stop, jump or other movement. Through long-term foot exercise, theoretically speaking, basketball players should have better physiological quality than ordinary people.

\section{Descriptions of Foot Pressure Test Regions}

There are a total of 10 test regions in the planta, namely $\mathrm{T} 1, \mathrm{~T} 2-\mathrm{T} 5, \mathrm{M} 1 \sim \mathrm{M} 5, \mathrm{MF}$ and $\mathrm{HM}$. $\mathrm{T} 1$ refers to the hallux, $\mathrm{T} 2^{\sim} \mathrm{T} 5$ refer to the $2^{\text {nd } ~} 5^{\text {th }}$ toes, and $\mathrm{M} 1 \sim \mathrm{M} 5$ refer to the $1^{\text {st } ~} 5^{\text {th }}$ metatarsals. MF (Mid Foot) stands for the mid foot [6]; HM (Heel Medial) stands for medial side of the heel; and $\mathrm{HL}$ (Heel Lateral) stands for the lateral side of the heel, as shown in Figure 1.

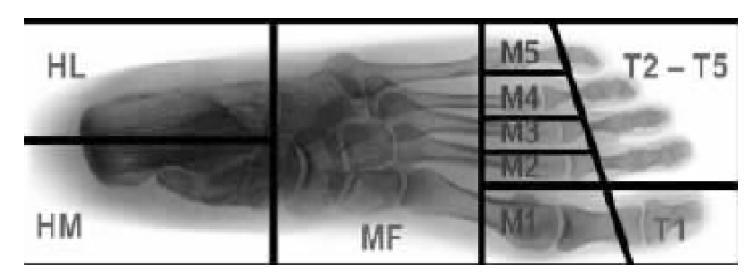

Figure 1. Foot pressure test area division map

In this paper, we test the following four groups of parameters of juvenile basketball players and ordinary juveniles: (1) initial contact phase, forefoot contact phase, foot flat phase and forefoot push off phase in a normal gait during the planta support period; (2) plantar pressure intensity, i.e. the pressure on the foot per unit of area (N/CM) [7]; (3) plantar impulse, i.e., the product of plantar pressure multiplied by action time (NS); (4) foot axis angle, i.e. the angle between the vertical axis of the foot and the walking direction $\left({ }^{\circ}\right)$. 


\section{Plantar Pressure Distribution Test}

\section{Test Subjects}

40 juvenile testees are involved in the foot pressure test, none of whom has any foot disease or injury. The testees are divided into an experimental group and a control group. The experimental group consists of 20 juvenile basketball players, all of whom are national Level 2 basketball players. The control group consists of 20 ordinary juveniles, none of whom has had any basketball training before. The basic information on the juveniles tested is listed in Table 1.

Table 1: The basic situation of the measured adolescents

\begin{tabular}{cccccc}
\hline Group & Gender & Weight $(\mathrm{kg})$ & Age & Foot size & Sports level \\
\hline Test group & Male & $63.2 \pm 10.2$ & $18.2 \pm 0.9$ & $41 \pm 2.2$ & National second-level athlete \\
Control group & Male & $62.2 \pm 8.6$ & $19.2 \pm 0.96$ & $41 \pm 2.5$ & None \\
\hline
\end{tabular}

\section{Test Equipment}

We adopt the RSscan footscan forcemeasuring system produced by a Belgian company [8] and use the Footscangaitscientific 7.97 software to store, analyze and extract the test data [9].

\section{Test Requirements}

1. In order to avoid the impacts of different shoe types and different individuals' fitness to shoe types on the test results, the juveniles are all barefoot during the test.

2. Considering the differences in the weights of the juveniles tested, in order to avoid the impacts of different weights on plantar pressure distribution, we carry out a pressure/ weight standardization process to make sure the objectivity of the test data - recording the pressure value as a multiple of the weight.

\section{RESULTS AND DISCUSSION}

\section{Test Results}

\section{Time Phase Distribution of the Planta Support} Period

During a normal gait, when the right and left feet are contacting the ground, there are four time phases - initial contact phase, forefoot contact phase, foot flat phase and forefoot push off phase [10]. Table 2 shows the statistics of the foot-ground contact time percentage in each phase.

Table 2: Comparison of the proportion of each phase value between test group and control group in different periods

\begin{tabular}{ccccc}
\hline Phase & \multicolumn{2}{c}{ Left foot } & \multicolumn{2}{c}{ Right foot } \\
& Test group & Control group & Test group & Control group \\
\hline Landing stage & $4.27 \pm 2.32$ & $3.47 \pm 1.46$ & $4.37 \pm 1.56$ & $3.51 \pm 1.75$ \\
Forefoot contact & $10.08 \pm 4.94$ & $7.56 \pm 5.63$ & $8.24 \pm 4.38$ & $6.24 \pm 5.79$ \\
Full contact & $38.04 \pm 7.62$ & $40.52 \pm 10.72$ & $32.38 \pm 8.92$ & $40.72 \pm 11.18$ \\
Off the ground & $53.61 \pm 6.03^{*}$ & $48.45 \pm 8.59$ & $55.01 \pm 8.21 \Delta$ & $49.53 \pm 9.37$ \\
Total & 100 & 100 & 100 & 100 \\
\hline
\end{tabular}

From the table, we can see that there is a significant difference between the times phases of the right and left feet in the push-off phase $\left({ }^{*} \mathrm{P}<0.05, \Delta \mathrm{P}<0.05\right)$. Statistically speaking, the difference is very significant [11].
Figure 2 shows that the time phase distribution of the right and left feet contacting the ground during four time phases. 


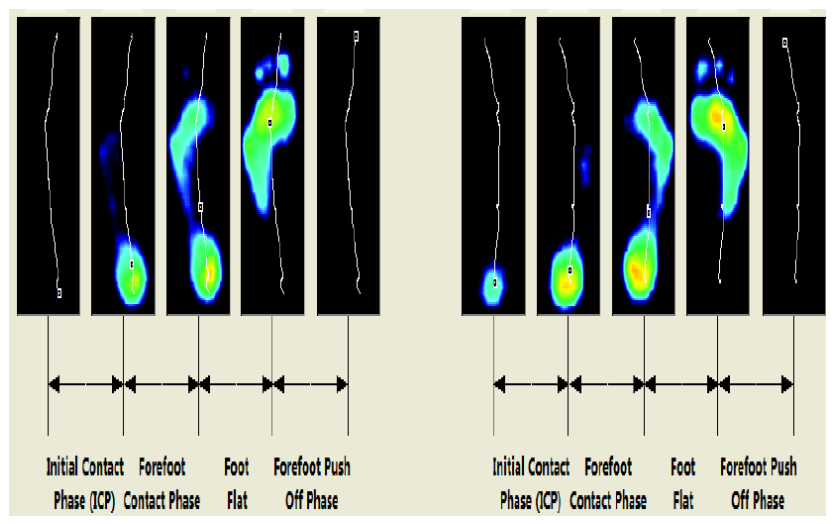

Figure 2. Time phase distribution of the foot support period

Peak Plantar Pressure

The foot can be divided into forefoot region, arch region and heel region. According to the regions shown in Figure 1, we compare the pressure values of the right and left feet [12]. The test results are shown in Table 3.

Table 3: Comparison of pressure peak/body weight between the test group and the control group $(\mathrm{N} / \mathrm{Kg})$

\begin{tabular}{|c|c|c|c|c|}
\hline \multirow[t]{2}{*}{ Phase } & \multicolumn{2}{|c|}{ Left foot } & \multicolumn{2}{|c|}{ Right foot } \\
\hline & Test group & Control group & Test group & Control group \\
\hline $\mathrm{T} 1$ & $1.12 \pm 0.27$ & $0.98 \pm 0.16$ & $1.47 \pm 0.36$ & $1.16 \pm 0.22$ \\
\hline T2-5 & $0.23 \pm 0.14$ & $0.19 \pm 0.08$ & $0.25 \pm 0.12$ & $0.21 \pm 0.11$ \\
\hline M1 & $3.27 \pm 0.63$ & $3.31 \pm 0.35$ & $3.42 \pm 0.58$ & $3.18 \pm 0.77 *$ \\
\hline M2 & $3.08 \pm 0.72$ & $3.04 \pm 0.61$ & $3.67 \pm 0.96 *$ & $3.08 \pm 0.23$ \\
\hline M3 & $0.92 \pm 0.14$ & $0.58 \pm 0.15$ & $0.76 \pm 0.19$ & $0.53 \pm 0.13$ \\
\hline M4 & $3.11 \pm 0.58$ & $2.79 \pm 0.41$ & $3.14 \pm 0.47$ & $2.85 \pm 0.36$ \\
\hline M5 & $1.79 \pm 0.47$ & $1.53 \pm 0.21$ & $1.74 \pm 0.36$ & $1.36 \pm 0.22$ \\
\hline MF & $2.96 \pm 0.43$ & $3.04 \pm 0.36$ & $2.77 \pm 0.34$ & $2.91 \pm 0.28$ \\
\hline HM & $2.83 \pm 0.31$ & $2.11 \pm 0.23$ & $1.95 \pm 0.29$ & $2.116 \pm 0.37$ \\
\hline $\mathrm{HL}$ & $0.61 \pm 0.17$ & $0.74 \pm 0.11$ & $0.55 \pm 0.13$ & $0.63 \pm 0.25$ \\
\hline
\end{tabular}

From the table, we can see that the peak pressure in the forefoot region in the experimental group is greater than that in the control group, while the peak pressure in the arch and heel regions is smaller than that in the control group [13]. The maximum peak pressure in the experimental group appears in the $\mathrm{M} 2$ region while that in the control group appears in the M1 region [14], indicating that the foot power of juveniles trained in basketball sports is significantly greater than that of the control group. The two has a statistic difference $\left({ }^{*} \mathrm{P}<0.05\right)$.

\section{Peak Plantar Pressure Intensity}

In the plantar pressure intensity test, the distribution of plantar pressure intensity is as follows: forefoot region>heel region>arch region. The test result shows that the overall pressure intensity of the experimental group is greater than that of the control group [15]. Details of test data are shown in Table 4.

Table 4: Pressure intensity peak distribution of the test group and the control group $\left(\mathrm{N} / \mathrm{cm}^{2}\right)$

\begin{tabular}{ccccc}
\hline Phase & \multicolumn{2}{c}{ Left foot } & \multicolumn{2}{c}{ Right foot } \\
& Test group & Control group & Test group & Control group \\
\hline T1 & $9.22 \pm 0.67$ & $7.81 \pm 0.74$ & $4.68 \pm 0.47$ & $4.12 \pm 0.86$ \\
T2-5 & $1.23 \pm 0.16$ & $1.12 \pm 0.28$ & $2.85 \pm 0.17$ & $1.91 \pm 0.14$
\end{tabular}




\begin{tabular}{ccccc} 
M1 & $6.91 \pm 1.72$ & $5.72 \pm 2.21$ & $12.76 \pm 1.84$ & $11.87 \pm 1.42^{*}$ \\
M2 & $23.26 \pm 2.75 \Delta$ & $19.89 \pm 1.86$ & $20.21 \pm 2.44^{*}$ & $17.61 \pm 2.37$ \\
M3 & $10.65 \pm 2.47$ & $8.02 \pm 1.96$ & $18.97 \pm 2.03$ & $15.54 \pm 1.89$ \\
M4 & $2.36 \pm 0.52$ & $2.16 \pm 0.66$ & $6.82 \pm 1.12$ & $4.95 \pm 0.82$ \\
M5 & $2.18 \pm 0.37$ & $1.81 \pm 0.24$ & $1.86 \pm 0.41$ & $1.74 \pm 0.36$ \\
MF & $1.64 \pm 0.26$ & $1.43 \pm 0.31$ & $1.22 \pm 0.27$ & $1.39 \pm 0.22$ \\
HM & $6.88 \pm 1.16$ & $6.04 \pm 0.96$ & $7.53 \pm 0.83$ & $6.74 \pm 0.56$ \\
HL & $8.38 \pm 1.27$ & $7.78 \pm 1.39$ & $9.82 \pm 1.57$ & $7.89 \pm 1.28$ \\
\hline
\end{tabular}

From the table, we can see that the maximum peak pressure intensity of the right and left feet appears in the $M 2$ region $\left(2^{\text {nd }}\right.$ metatarsal). Statistically speaking [16], there is a statistic difference between the experimental group and the control group ( $\left.{ }^{*} \mathrm{P}<0.05, \Delta \mathrm{P}<0.05\right)$.

\section{Plantar Impulse}

Similar to the distribution of plantar pressure intensity, the distribution of plantar impulse is also as follows: forefoot region>heel region>arch region. And the test result shows that the plantar impulse of the experimental group is smaller than that of the control group [17]. Details of test data are shown in Table 5.

Table 5: Impulse distribution of the test group and the control group (NS)

\begin{tabular}{ccccc}
\hline Phase & \multicolumn{2}{c}{ Left foot } & \multicolumn{2}{c}{ Right foot } \\
\hline & Test group & Control group & Test group & Control group \\
T1 & $18.23 \pm 5.74$ & $21.62 \pm 6.43$ & $25.88 \pm 4.61$ & $29.17 \pm 5.33$ \\
T2-5 & $3.61 \pm 1.27$ & $4.28 \pm 1.88$ & $6.45 \pm 1.28$ & $8.84 \pm 2.16$ \\
M1 & $16.85 \pm 4.92$ & $19.65 \pm 6.32$ & $35.76 \pm 5.61$ & $38.92 \pm 6.61$ \\
M2 & $35.83 \pm 4.77$ & $39.68 \pm 6.37$ & $53.74 \pm 7.86^{*}$ & $57.71 \pm 8.09$ \\
M3 & $43.52 \pm 5.82 \Delta$ & $46.28 \pm 6.29$ & $48.91 \pm 7.93$ & $52.26 \pm 7.97$ \\
M4 & $32.96 \pm 5.61$ & $36.11 \pm 6.75$ & $34.83 \pm 6.62$ & $37.35 \pm 748$ \\
M5 & $21.73 \pm 6.44$ & $23.67 \pm 7.85$ & $12.64 \pm 4.73$ & $16.69 \pm 5.22$ \\
MF & $23.28 \pm 4.63$ & $26.92 \pm 5.94$ & $15.11 \pm 6.17$ & $19.13 \pm 6.59$ \\
HM & $41.84 \pm 3.02$ & $45.96 \pm 4.87$ & $51.83 \pm 4.64$ & $56.81 \pm 6.04$ \\
HL & $35.57 \pm 4.82$ & $38.31 \pm 6.06$ & $44.21 \pm 5.23$ & $50.86 \pm 4.63$ \\
\hline
\end{tabular}

The maximum impulse of the left foot appears in the $\mathrm{M} 3$ region ( $2^{\text {nd }}$ metatarsal) and that of the right foot appears in the $\mathrm{M} 2$ region ( $3^{\text {rd }}$ metatarsal). The two have a statistic difference $\left({ }^{*} \mathrm{P}<0.05, \Delta \mathrm{P}<0.05\right)$.

\section{Foot Axis Angle}

During normal gaits, vertically, the foot axis angle shows the changes in the foot stability while horizontally it can be used to compare the differences in the foot stability features. From Table 6, it can be seen that the foot axis angles of the right and left feet in the experimental group are all greater than those in the control group.

Table 6: Foot axis angles of the right and left feet in the experimental group

\begin{tabular}{ccc}
\hline Group & Left foot & Right foot \\
\hline Test group & $10.2 \pm 1.7^{*}$ & $11.3 \pm 2.6 \Delta$ \\
Control group & $7.8 \pm 2.2$ & $8.9 \pm 1.5$ \\
\hline
\end{tabular}

Figure 3 shows the distribution of foot axis angles of the testees in the experimental group. The dotted lines in the figure are the vertical axes, and the angles between the red solid lines and the vertical axes are the foot axis angles. The colors which change from dark to light represent the plantar pressure distribution.

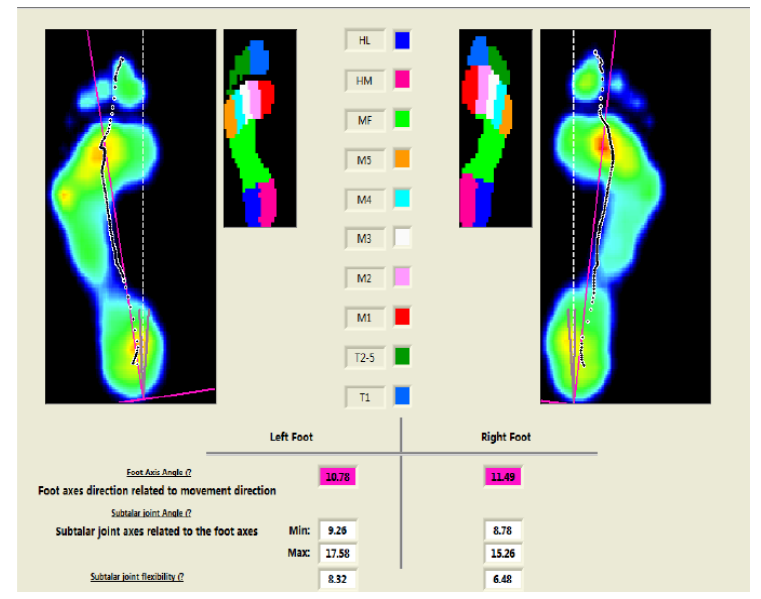

Figure 3. The foot angle distribution diagram of test group 


\section{Analysis of Test Results}

\section{Time Phase Analysis of the Support Period}

In terms of the time phase of the push off stage, there is a significant difference between the experimental group and the control group, indicating that playing basketball on a longterm basis has an effect on the foot power in normal gaits. In normal gaits, the forefoot region is subject to prolonged pressure, so pressure is concentrated in the center. This shows that through long-time high-intensity basketball training and exercise, the foot power against the ground is more persistent. This indicates that after basketball training, players should pay attention to the rehabilitation of their feet and carry out mild exercise, to avoid fasciitis, Achilles tendinitis and other inflammations in their feet and muscle joints.

By conducting time phase analysis of the experimental group and the control group during the support period, we will understand how to make reasonable teaching plans and determine a scientific load training intensity for basketball sports.

\section{Feature Analysis of Foot Power}

Based on the test results of plantar pressure distribution and plantar pressure intensity distribution, we can analyze the foot power features. The feature of plantar pressure distribution is that forefoot region>arch region>heel region. The peak forefoot pressure and pressure intensity of the testees in the experimental group are all greater than those in the control group, indicating that in normal gaits, the power generated by the basketball players in the experimental group are greater than that by the ordinary juveniles in the control group and further showing that basketball can help increase foot power. In the arch and heel regions, the peak pressure intensity of the testees in the experimental group is less than that in the control group, indicating that the basketball players have better shock absorbing and buffering abilities, which can effectively mitigate impact injuries.

\section{Effect Analysis of Plantar Buffering Capacity}

Plantar impulse is an indicator of how well a foot can absorb the impacts and act as a buffer and is the accumulation of power and action time. The test results show that the impulses in the forefoot, arch and heel regions in the experimental group are smaller than those in the control group, indicating that through exercise, basketball players have better foot buffering capacity and can better absorb ground impacts. A good foot impulse buffering is of great significance to the protection of foot and knee joints, and is also helpful to improving the body's control and balance. This shows that basketball can help improve the overall motor function of juveniles and thus juveniles should be encouraged to participate in basketball training.

\section{Foot Stability Impact Analysis}

Foot axis angle refers to the angle between the longitudinal axis of the foot and the direction of walking. Medically speaking, when a foot axis angle is greater than $15^{\circ}$, the foot is abnormal. From the test data, it can be seen that the foot axis angles in the experimental group and the control group are in the normal range. The foot axis angles in the experimental group are greater than those in the control group, indicating that the experimental group have better abilities to control foot gaits. The increase of the foot eversion angle within a certain range can improve the contact area between the foot and the ground and increase the stability of the foot. Test results indicate that long-term participation in basketball sports can improve the foot stability, balance ability and coordination capacity of a juvenile.

\section{CONCLUSIONS}

Foot movements are one of the most critical part in basketball sports. Analyzing the effects of basketball on the foot support period, pressure, pressure intensity, foot impulse and foot axis angle is of great significance to scientifically guiding foot protection and evaluating the effects of basketball on foot movement abilities of juveniles. In this paper, through an experiment, we compare the experimental group and the control group and use the RS-footscan force-measuring system to measure and analyze various parameters and indicators. The conclusions and guiding significance of this paper are as follows:

(1) Basketball prolongs the time during which the feet of juveniles are off the ground, so 
their foot buffering capacity and forefoot power are increased, and their foot stability is improved. Proper basketball exercise can help promote the foot health development of juveniles.

(2) Due to long-term training, pressure is relatively concentrated in the forefeet of the basketball players in the experimental group; therefore, players should relieve their foot pressure and reduce foot injuries by physical therapy and massage.

(3) Studying the foot dynamics with modern measurement methods can provide more scientific and objective data support, and thus it should be promoted more in the actual application.

\section{Acknowledgements}

2017 Chongqing Municipal Education Commission Humanities and Social Sciences Research (No. 17SKS15).

\section{References}

1. Eils, E., Streyl, M., Linnenbecker, S., Thorwesten, L., Völker, K., Rosenbaum, D., Characteristic plantar pressure distribution patterns during soccer-specific movements, Am J Sports Med, 2004, 32, 1, 140, https:// doi.org/10.1177/0363546503258932.

2. Horisberger, M., Hintermann, B., Valderrabano, V., Alterations of plantar pressure distribution in posttraumatic end-stage ankle osteoarthritis, Clin Biomech, 2009, 24, 3, 303-307, https://doi.org/10.1016/j. clinbiomech.2008.12.005.

3. Dick, R., Hertel, J., Agel, J., Grossman, J., Marshall, S.W., Descriptive epidemiology of collegiate men's basketball injuries: national collegiate athletic association injury surveillance system, 1988-1989 through 2003-2004, J Athl Train, 2007, 42, 2, 194.

4. James, D.C., Chesters, T., Sumners, D.P., Cook, D.P., Green, D.A., Mileva, K.N., Wide-pulse electricalstimulationto an intrinsic footmuscle induces acute functional changes in forefootrearfoot coupling behaviour during walking, Int J Sports Med, 2012, 34, 05, 438-443, https://doi.org/10.1055/s-0032-1321893.

5. Aquila, A., Giannini, S., Ferraresi, C., Berti, L., Leardini, A., Gait analysis with a multisegment foot model for the biomechanical validation of hinged foot-ankle orthoses,
Gait Posture, 2014, 40, S15-S15, https://doi. org/10.1016/j.gaitpost.2014.05.038.

6. Fernández-Seguín, L.M., Diaz Mancha, J.A., Sánchez, R.R., Escamilla, M.E., Gómez, M.B., Ramos, O.J., Comparison of plantar pressures and contact area between normal and cavus foot, Gait Posture, 2014, 39, 2, 789-792, https://doi.org/10.1016/j. gaitpost.2013.10.018.

7. Wu, G., Chiang, J.H., The effects of surface compliance on foot pressure in stance, Gait Posture, 1996, 4, 2, 122-129, https://doi. org/10.1016/0966-6362(95)01041-6.

8. Low, D.C., Dixon, S.J., Footscan pressure insoles: accuracy and reliability of force and pressure measurements in running, Gait Posture, 2010, 32, 4, 664-666, https://doi. org/10.1016/j.gaitpost.2010.08.002.

9. Franklyn-Miller, A., Wilson, C., Bilzon, J., \& Mccrory, P., Foot orthoses in the prevention of injury in initial military training: a randomized controlled trial, $A m$ J Sports Med, 2011, 39, 1, 30-7, https://doi. org/10.1177/0363546510382852.

10. Scranton, P.E., Jr, S. P., Pedegana, L.R., Whitesel, J.P., Gait analysis. Alterations in support phase forces using supportive devices, Am J Sports Med, 1982, 10, 1, 6.

11. Esparza, F., Abellàn, J., Ibañez, P., Sànchez Ayuso, J.M., Description of plantar pressure distribution in athletes, Br J Sports Med, 2011, 45, 4, 347-348, https://doi.org/10.1136/ bjsm.2011.084038.106.

12. Al-Angari, H.M., Khandoker, A.H., Lee, S., Almahmeed, W., Al Safar, H.S., Jelinek, H.F., et al., Novel dynamic peak and distribution plantar pressure measures on diabetic patients during walking, Gait Posture, 2017, 51, 261-267, https://doi.org/10.1016/j. gaitpost.2016.11.006.

13. Ullery, R., Nyland, J.A., Caborn, D.N.M., Medial patellar taping of female basketball players changes peak plantar pressure location and timing, Gait Posture, 1998, 30 (Supplement).

14. Lai, Y.C., Lin, H.S., Pan, H.F., Chang, W.N., Hsu, C.J., Renn, J.H., Impact of foot progression angle on the distribution of plantar pressure in normal children, Clin Biomech, 2014, 29, 2, 196-200.

15. Fourchet, F., Kelly, L., Horobeanu, C., Loepelt, 
H., Taiar, R., Millet, G.P., Comparison of plantar pressure distribution in adolescent runners at low vs. high running velocity, Gait Posture, 2012, 35, 4, 685-687, https://doi. org/10.4085/1062-6050-49.3.90.

16. Fourchet, F., Kelly, L., Horobeanu, C., Loepelt, H., Taiar, R., Millet, G., High-intensity running and plantar-flexor fatigability and plantarpressure distribution in adolescent runners, J Athl Train, 2015, 50, 2, 117, https://doi. org/10.4085/1062-6050-49.3.90.
17. Orlin, M., Stetson, K., Skowronski, J., Pierrynowski, M., Foot pressure distribution: methodology and clinical application for children with ankle rheumatoid arthritis, Clin Biomech, 1997, 12, 3, S17.

(C) 2018 by the author(s). Published by INCDTPICPI, Bucharest, RO. This is an open access article distributed under the terms and conditions of the Creative Commons Attribution license (http:// creativecommons.org/licenses/by/4.0/). 